\title{
Biogas and Bio-fertilizer Production Potential of Abattoir Waste as Means of Sustainable Waste Management Option in Hawassa City, Southern Ethiopia
}

\author{
${ }^{1}$ SINDIBU, T;*2SOLOMON, SS; ${ }^{2}$ ERMIAS, D \\ ${ }^{I}$ Department of Environmental Sciences, College of Health and Medical Sciences, Haromaya University, Ethiopia \\ ${ }^{2}$ Department of Biology, Hawassa University, Hawassa, Ethiopia \\ *Corresponding Author Email: sorsasota@yahoo.com; Phone: +251916828248
}

\begin{abstract}
The purpose of this study was to assess abattoir waste generation in Hawassa Municipality Abattoir (HMA) andits potential to produce biogas and bio-fertilizer employing a cross-sectional design and mathematical computation based on standard coefficients. The study demonstrated that HMA generates $885,881.6 \mathrm{Kg}$ of abattoir waste per year and using anaerobic digestion about $46,951.72 \mathrm{~m}^{3} / \mathrm{year}$ of biogas can be produced. This waste has the potential of generating a total energy of $246,027.01 \mathrm{KWh} /$ year. The biogas or energy from the waste can replace the biomass (firewood and charcoal) and the expensive fossil fuels. Using the produced $46,951.72 \mathrm{~m}^{3} /$ year biogas could reduce the annual $\mathrm{CO}_{2}$ emission of $150,600.10 \mathrm{Kg} / \mathrm{kWh}$ from kerosene, $150,600.10 \mathrm{Kg} / \mathrm{kWh}$ from petrol, $132,882.50 \mathrm{Kg} / \mathrm{kWh}$ from diesel or $132,882.50 \mathrm{Kg} / \mathrm{kWh}$ from LPG use. The abattoir will be able to produce an estimated $65,112.3 \mathrm{Kg} /$ year dry bio-fertilizer from biogas technology and this bio-fertilizer can be supplied to local farmers for crop production or can be used by city municipality for growing plants used for beautification. This obtainable bio- fertilizer is valued 29,951.66 USDper annum and to a certain extent will contribute to the reduction of domestic demand of chemical fertilizer thus will reduce the annual budget. As a long-term and sustainable waste management solution, installing anaerobic digestion plant is recommended, but using proper disposal method among the existing would serve as a short-term solution.
\end{abstract}

DOI: https://dx.doi.org/10.4314/jasem.v22i4.21

Copyright: Copyright () 2018 Sindibu et al. This is an open access article distributed under the Creative Commons Attribution License (CCL), which permits unrestricted use, distribution, and reproduction in any medium, provided the original work is properly cited.

Dates: Received: 13 February; Revised: 08 April: 2018; Accepted: 20 April 2018

Key-words: - Abattoir, Bio-fertilizer, Biogas, Energy, Hawassa, Waste

According to Chukwu (2008), the most important cause of improper management of abattoir waste is absence and lack of properly designed abattoir; lack of regulations on restriction and prohibition of indiscriminate and unsafe wastes discharge; insufficient skill of waste handlers; poor quality of equipment and lack of political commitment and awareness. Some people also argue that the practice is mainly due to lack of or inadequate waste recovery and treatment facilities (Adeyemo et al., 2009).

According to Cvetković et al. (2014), abattoir waste is an ideal substrate for biogas production, because it contains high concentration of organic matter (proteins and lipids).According to Amigun and Blottnitz (2010) and B-Sustain (2013a) the economic benefits of biogas technology include the financial benefits, social benefits to environment, health, employment, gender, and poverty reduction benefits. Although abattoir wastes could be of potential benefits, their improper disposal is a serious problem in many developing countries (Adeyemi et al., 2007) and are a major source of public health and environmental hazards if they are not treated (FAO, 2010).

The above descriptions clearly show that it is possible that part of the abattoir wastes in cities and towns of Ethiopia can be used to produce biogas and associated valuable products. Hawassa Municipality Abattoir (HMA) has been releasing its untreated abattoir waste into the open surrounding environment indicating poor waste management practice. Therefore, the main purpose of the study was to assess the amount of waste generated by HMA and to determine its potential to produce biogas and bio-fertilizer as means of sustainable waste management.

\section{MATERIALS AND METHODS}

Description of the study area: Hawassa Municipality Abattoir is in Hawassa city, the capital of Southern Nations, Nationalities and Peoples Region (SNNPR) which is located $275 \mathrm{~km}$ away from Addis Ababa. Hawassa city has an elevation ranging from 1,692 to 
$1,742 \mathrm{~m}$ above sea level and it is located at 7005' North latitude and 38029' East longitude. The total surface area of the city is $157.2 \mathrm{~km}^{2}$. According to CSA (2015) report, Hawassa city has a population of 351,469 , with an annual growth rate of just over $4 \%$. The climate of the City characterized in warm temperate climatic zone with a mean annual precipitation of $956 \mathrm{~mm}$, with extended period of wet season (March- October with varying monthly rainfall from $17 \mathrm{~mm}-126 \mathrm{~mm}$ in the month between January - September), and the mean annual temperature of $19.5^{\circ} \mathrm{C}$ ( Kirubel, 2015).

Study Design and Approach: A cross-section design and mathematical computations based on standard coefficients and measurements were employed in this study.

Abattoir Waste Generation (AWG) Estimation Method: The actual numbers of slaughtered cattle during the study period (March 2015 to February 2016) was obtained from data recorded of HMA office. The amount of waste compositions generated from the slaughtered cattle was estimated based on Anieboet al. (2009) mathematical computation. According to Anieboet al. (2009), one cattle in average could produce waste of $6.4 \mathrm{Kg}$ tissue, $8.0 \mathrm{Kg}$ of intestinal content, and $11.8 \mathrm{Kg}$ of bone and $12.6 \mathrm{Kg}$ of blood. In this study, the above mentioned four waste types (tissue, intestinal content, bone and blood) were considered.

Biogas Production Potential and Energy Potential Estimation Method:Biogas production potential of abattoir waste was estimated following the coefficient described in Ngumahet al. (2013). According to this method, 1 ton $(1000 \mathrm{Kg})$ of abattoir waste can produce $53 \mathrm{~m}^{3}$ biogas that is $1 \mathrm{Kg}$ of abattoir waste can produce $0.053 \mathrm{~m}^{3}$ of biogas. Hence, the volume of biogas produced (VBP) may be obtained using the following formula (eqn. 1):

$\mathrm{VBP}=\mathrm{AWG} * 0.053 \mathrm{~m}^{3} / \mathrm{kg}$

According to Ngumahet al. (2013), the energy potential of biogas generated is based on the calorific value (high heating value) of the methane content and Rohstoffe (2009) stated that the average calorific value of biogas is $21-23.5 \mathrm{MJ} / \mathrm{m}^{3}$ (approximately $22.0 \mathrm{MJ} /$ $\mathrm{m}^{3}$ ). Commonly, energy is expressed as Kilo Watt hour $(\mathrm{KWh})$ and $3.6 \mathrm{MJ}$ is equal to $1 \mathrm{KWh}$. If the 22.0 $\mathrm{MJ} / \mathrm{m}^{3}$ of biogas is converted to $\mathrm{KWh}, 1 \mathrm{~m}^{3}$ of biogas has an energy potential of $6.1 \mathrm{KWh}$.

Energies (electricity and heat) potential of biogas was estimatedbased on the energy conversion methods formulated by Banks (2009). According to Banks (2009), the efficiency of biogas to be converted to electricity is $35 \%$ and, therefore, the electricity production potential of $1 \mathrm{~m}^{3}$ of biogas is $2.14 \mathrm{KWh}$ (i.e. its energy potential of $6.1 \mathrm{KWh} \mathbf{X} 0.35$ ). Therefore, the Electricity production potential (EPP), (KWh), may be obtained using the following formula:

$\mathrm{EPP}=\mathrm{VBP} \mathrm{m}^{3} * 2.14 \mathrm{KWh} / \mathrm{m}^{3}$

Similarly, Banks (2009) indicated that the efficiency of biogas to be converted to heat energy is $50 \%$ and, thus the heat production potential of $1 \mathrm{~m}^{3}$ of biogas is $3.1 \mathrm{KWh}$ (i.e. energy potential of $6.1 \mathrm{KWh} \mathbf{X} 0.5$ ). The heat production potential (HPP), (KWh), may be estimated as:

$\mathrm{HPP}=\mathrm{VBP} \mathrm{m}^{3} * 3.1 \mathrm{KWh} / \mathrm{m}^{3}$

Bio-Fertilizers Yield Potential Estimation Methods: According to Ngumahet. al. (2013), the coefficients used in estimating bio-fertilizer yields were based on the fraction of the dry mass portion of organic waste that is not converted to biogas. Therefore, in this study, bio-fertilizer was estimated based on the coefficient fraction of the Dry Mass (DM) and Volatile Solid (VS) portion of abattoir waste. According to Dublein and Steinhauser (2008), the DM percentage of fresh organic wastes was given as $15 \%$ for abattoir waste, while the VS percentage of the DM was given as $85 \%$. In this study, the following formulas were used for calculating DM and VS.

$$
\begin{aligned}
& \mathrm{DM}=\mathrm{AWG}(\mathrm{kg}) * 0.15(15 \%) \\
& \mathrm{VS}=\mathrm{DM} * 0.85(85 \%)
\end{aligned}
$$

Based on Dublein and Steinhauser (2008) principle, the Bio-Fertilizer Yield (BFY) of the abattoir waste was calculated considering DM (equations 4) and VS (equation 5). But according to Burke (2000), 60\% of VS is the actual fraction taken to be converted to biogas and therefore, the remaining $40 \%$ portion of VS 
was considered in BFY computation. Hence the following formula for computing the potential of BFY was deduced as:

$\mathrm{BFY}=(\mathrm{DM}-\mathrm{VS})+(40 \%$ of $V S)$

\section{RESULTS AND DISCUSSION}

Currently, HMA provides only cattle slaughtering service and the number of slaughtered cattle during the study period are presented in Table 1.The average number of slaughtered cattle were 63 per day, 429 per week, 1859 per month and 22,832 per year (Table 1). The result revealed that the slaughtered number of cattle in each month was varied and this seems to be due to different fasting periods and different holidays and, also due to occasional festivity happened in the year. The number of cattle slaughtered per day in HMA was lower than that reported by Mummed and Webb (2015) for Elfora Kombolcha abattoir (275/day), Adama abattoir (200/day) and Mekele abattoir (125/day) in Ethiopia.

The present study demonstrated that HMA generates $2,456.04 \mathrm{Kg}$ and $885,881.6 \mathrm{Kg}$ of abattoir waste per day and year, respectively (Table 1). This generation amount is consistent with the finding of Ahaneku et al. (2015) $(2,394 \mathrm{Kg} /$ day and $873,810 \mathrm{Kg} /$ year) from Mina abattoir in Nigeria, but is less than that reported for Elfora Kombolcha, Adama and Mekele abattoirs in Ethiopia.Slightly lower generation $(2,134 \mathrm{Kg} /$ day and $778,910 \mathrm{Kg} /$ year) was also reported from Temale abattoir in Ghana (Frederick et al., 2010). These differences appear to be due to the difference in the cattle slaughtering capacities.

The results indicated that blood waste accounted the highest $(32.5 \%)$ among the types of abattoir waste generated annually (Table 1). Consistent with the present study, Aneiboet al. (2009) stated that blood waste is huge as compared to other abattoir waste compositions and discharging of blood into sewer line from single slaughtered cattle is equivalent to the total sewage produced by 50 people on average per day. Therefore, blood waste generated per day in this study (i.e. from 63.26 of slaughtered cattle) was equivalent to a total effluent load of sewage produced by 3,163
people/day.Bones waste was the second highest with a generation of $746.94 \mathrm{Kg} /$ day and $269,417.6 \mathrm{Kg} /$ year (Table 1). This result is similar to the findings reported by Ahaneku et al (2015) (i.e.728Kg/day and $262,078 \mathrm{Kg} /$ year) from Minna abattoir, in Nigeria; and higher (i.e. $649 \mathrm{Kg} /$ day and $236,885 \mathrm{Kg} /$ year) than that reported from Temale abattoir, in Ghana (Fredericket al., 2010).The intestinal content wastes generation recorded in this study $(506.4 \mathrm{Kg} /$ day and $182,656.0 \mathrm{Kg} /$ year) was consistent with the finding of Oruonye (2015) (i.e. $500 \mathrm{Kg} /$ day and $1,825 \mathrm{Kg} / \mathrm{year}$ ) in Jalingo Metropolis abattoir, Nigeria. Moreover, the tissue wastes generated $(405.12 \mathrm{Kg} /$ day and $146,124.8 \mathrm{Kg} /$ year) also agree with finding in Nigeria (Oruonye, 2015).

Estimation of Biogas Production: The present study indicated that using anaerobic digestion; about $130.17 \mathrm{~m}^{3} /$ day and $46,951.72 \mathrm{~m}^{3} /$ year of biogas can be produced from $2,456.06 \mathrm{Kg} /$ day and $885,881.6 \mathrm{Kg} /$ year of abattoir waste generated in HMA, respectively (Table 2). The daily biogas production potential recorded in this study was less than that reported by Mummed and Webb (2015) for Elfora Kombolcha $\left(557 \mathrm{~m}^{3} /\right.$ day), Adama $\left(406 \mathrm{~m}^{3} /\right.$ day) and Mekele $\left(253 \mathrm{~m}^{3} /\right.$ day) abattoirs in Ethiopian. But, almost similar annual biogas production potential was reported from Minna abattoir (Nigeria) $\left(45,672.64 \mathrm{~m}^{3} /\right.$ year) (Frederick et al., 2010) and Temale abattoir (Ghana) $\left(40,716.72 \mathrm{~m}^{3} /\right.$ year) (Adzabe et al., 2005).

Energy Production Potential from Biogas: Results (Table 3) indicated that the $130.17 \mathrm{~m}^{3} /$ day and $46,951.72 \mathrm{~m}^{3} /$ year of biogas produced from HMA waste has the potential of generating a total energy of $682.09 \mathrm{KWh}$ /day $(278.56 \mathrm{KWh}$ of electricity and $403.53 \mathrm{KWh}$ of heat) and $246,027.01 \mathrm{KWh} /$ year $(100,476.68 \mathrm{KWh}$ electricity and 145,550.33 KWh of heat) (Table 3). According to Electrigas (2016), 2 $\mathrm{KWh}$ of electricity is sufficient to run a $100 \mathrm{~W}$ light bulb for 20 hours. Therefore, the biogas produced in HMA daily $\left(130.17 \mathrm{~m}^{3}\right)$ can run $100 \mathrm{~W}$ light bulb for 1,301.7 hrs. The potential of generated electricity can be used by HMA to meet its energy need, and the energy (electricity and heat) in surplus of the abattoir can be supplied to communities in the vicinity. According to Ethiopian Electric Power Corporation (EEPCO, 2015), the minimum cost (tariff) of $1 \mathrm{KWh}$ 
of electricity or heat is 0.021USD (0.57 ETB). And if all the energy potential is utilized, the abattoir can save 14.3USD/day or 5,166.6 USD/year of its budget (Table 3).The potential biogas or energy (electricity and heat) generated from the waste can replace the biomass (firewood and charcoal) and the expensive fossil fuels (kerosene, petrol, liquefied petroleum gas (LPG), diesel, and furnace oil). As CIA (2008) reported, many people in Ethiopia still use the same traditional fuels (firewood or charcoal, dung).

According to B-sustain (2013b) biogas equivalent to fossil fuels conversion method, $1 \mathrm{~m}^{3}$ of biogas is equivalent to $3.50 \mathrm{Kg}$ of charcoal/firewood, $0.6 \mathrm{Kg}$ of kerosene, $0.45 \mathrm{Kg}$ of LPG, $0.4 \mathrm{Kg}$ of furnace oil, 0.7 $\mathrm{Kg}$ of petrol and $0.5 \mathrm{Kg}$ of diesel. Firewood, charcoal and kerosene are commonly used as domestic fuels in the study area and result (Table 4) of this study showed that the biogas generated from HMA waste can replace consumption of $455.6 \mathrm{Kg} /$ day and $164,331.0 \mathrm{Kg} /$ year of firewood/charcoal, and $78.1 \mathrm{Kg} /$ day and $28,171.0$ $\mathrm{Kg} /$ year kerosene. As described by Ngumah et al. (2013), displacing firewood, charcoal and kerosene will reduce demand for firewood and consequently deforestation, and prevent many ailments and deaths associated with indoor pollution due to use of these fuels in domestic cooking.

Table1. Number of cattle slaughtered and Composition of Abattoir Waste Generation

\begin{tabular}{lllllll}
\hline $\begin{array}{l}\text { Duration/ } \\
\text { period }\end{array}$ & $\begin{array}{l}\text { Average } \\
\begin{array}{l}\text { No. of } \\
\text { cattle }\end{array}\end{array}$ & \multicolumn{5}{c}{ Abattoir waste composition and generation (Kg) } \\
\cline { 3 - 7 } & & Blood & Intestinal contents & Bone & Tissue & Total \\
\hline Day & 63.3 & 797.58 & 506.4 & 746.94 & 405.12 & $2,456.04$ \\
Week & 429.1 & $5,406.66$ & $3,432.80$ & $5,063.38$ & $2,746.24$ & $16,649.08$ \\
Month & $1,859.4$ & $23,428.44$ & $14,875.20$ & $21,940.92$ & $11,900.16$ & $72,144.72$ \\
Year & $22,832.0$ & $287,683.2$ & $182,656.0$ & $269,417.6$ & $146,124.8$ & $885,881.6$ \\
\hline
\end{tabular}

Table 2. Biogas production potential of waste generated from HMA

\begin{tabular}{llll}
\hline Duration & $\begin{array}{l}\text { No. of cattle } \\
\text { slaughtered }\end{array}$ & $\begin{array}{l}\text { Abattoir waste } \\
\text { generated }(\mathbf{K g})\end{array}$ & $\begin{array}{l}\text { Amount of Biogas } \\
\text { produced }\left(\mathbf{m}^{3}\right)^{*}\end{array}$ \\
\hline Day & 63.3 & $2,456.04$ & 130.17 \\
Week & 429.1 & $16,649.08$ & 882.40 \\
Month & $1,859.4$ & $72,144.72$ & $3,823.67$ \\
Year & $22,832.0$ & $885,881.6$ & $46,951.72$ \\
\hline \multicolumn{2}{c}{ *1 Kg of abattoir waste can produce $0.053 \mathrm{~m}^{3}$ of biogas (equation 1) }
\end{tabular}

Table 3. Energy potential of biogas produced from HMA waste and Cost Estimate

\begin{tabular}{|c|c|c|c|c|c|c|}
\hline \multirow{3}{*}{ Duration } & \multirow{3}{*}{$\operatorname{Biogas}\left(\mathbf{m}^{3}\right)$} & \multicolumn{4}{|c|}{$\begin{array}{l}\text { Estimated Energy Potential from Biogas and its Cost } \\
\text { Benefit }\end{array}$} & \multirow{3}{*}{$\begin{array}{l}\text { Total Energy } \\
\text { (KWh) and cost } \\
\text { (USD) }\end{array}$} \\
\hline & & \multicolumn{2}{|c|}{ Electric (KWh) } & \multicolumn{2}{|c|}{ Heat (KWh) } & \\
\hline & & $\begin{array}{l}\text { Amount } \\
\text { (KWh) }\end{array}$ & $\begin{array}{c}\text { Cost } \\
(* \text { USD) }\end{array}$ & $\begin{array}{l}\text { Amount } \\
\text { (KWh) }\end{array}$ & $\begin{array}{l}\text { Cost } \\
(* \text { USD) }\end{array}$ & \\
\hline Day & 130.17 & 278.56 & 5.8 & 403.53 & 8.5 & $14.3(682.09)$ \\
\hline Week & 882.40 & $1,888.34$ & 39.7 & $2,735.44$ & 54.4 & $97.1(4,623.78)$ \\
\hline Month & $3,823.67$ & $8,182.65$ & 171.8 & $11,853.38$ & 248.9 & $420.7(20,036.03)$ \\
\hline Year & $46,951.72$ & $100,476.68$ & $2,110.0$ & $145,550.33$ & $3,056.6$ & $15,166.6(246,027)$. \\
\hline
\end{tabular}

Carbon Dioxide $\left(\mathrm{CO}_{2}\right)$ Emission Reduction Benefit of Using Biogas: Studies (B-Sustain, 2013a; Ngumah et al., 2013) indicated that utilization of biogas energy using biogas technology reduces the $\mathrm{CO}_{2}$ emission through reduction of the demand for fossil fuels. Results (Table 5) of the recent study showed that using $46,951.72 \mathrm{~m}^{3} /$ year of biogas produced from HMA could reduce the annual $\mathrm{CO}_{2}$ emission of
$150,600.10 \mathrm{Kg} / \mathrm{kWh}$ from kerosene, $150,600.10 \mathrm{Kg} / \mathrm{kWh}$ from petrol, $132,882.50 \mathrm{Kg} / \mathrm{kWh}$ from diesel or $132,882.50 \mathrm{Kg} / \mathrm{kWh}$ from LPG use. Therefore, using biogas produced from waste of HMA instead of LPG, kerosene, and petrol and diesel fuels can reduce environmental impacts of $\mathrm{CO}_{2}$. At the same time, as B-Sustain (2013a) indicated, by capturing uncontrolled methane emission, the second most

SINDIBU, T; SOLOMON, SS; ERMIAS, D 
important greenhouse gas (methane) emission also can be reduced.

Estimation of Bio-fertilizer Production and its Benefits: Based on equation 4, a total of $368.4 \mathrm{Kg} /$ day and 132,882.2 Kg/year of DM can be produced (Table 6 ) from HMA solid waste generated. Moreover, based on equation 5 , an estimated $313.2 \mathrm{Kg} /$ day and $112,949.9 \mathrm{Kg} /$ year of VS can be produced (Table 6). From this DM and VS, the abattoir will be able to produce an estimated $180.5 \mathrm{Kg} /$ day and $65,112.3$ $\mathrm{Kg} /$ year dry bio-fertilizer from biogas technology. This potential bio-fertilizer generated can be supplied to local farmers for crop production or can be used by city municipality for growing plants used for beautification of the city. According to the information from Ethiopian Ministry of Agriculture (Personal communication, 2016), the price of bio-fertilizer also estimated based on the current average price of Ethiopian chemical/inorganic fertilizer, i.e. $50 \mathrm{Kg}$ of UREA fertilizers costs 45.56USD(1,230 ETB) and $50 \mathrm{Kg}$ of DAP fertilizer equals to 53.89USD (1,455ETB). Ngumah et al. (2013) noted that biofertilizer is more useful than chemicals fertilizer. However, according to the information from Energy and Biogas program expert in SNNPR Bureau of Agriculture, (Personal communication SNNPR Bureau of Agriculture, 2016), due to farmers' and users limited awareness about its benefits and to attract them, the price of bio-fertilizer should be reduced by half $(50 \%)$ of inorganic fertilizers (i.e. DAP and UREA). Therefore, based on the above suggestion, the average current cost estimation for $50 \mathrm{Kg}$ bio-fertilizer would be $22.78 \mathrm{USD} / 615.0 \mathrm{ETB}$ or $1 \mathrm{Kg}$ of biofertilizer costs $0.46 \mathrm{USD} / 12.3 \mathrm{ETB}$. According to the results (Table 6) using biogas technology, HMA has a potential of producing $180.52 \mathrm{Kg} /$ day and $65,112.30 \mathrm{Kg} /$ year of bio-fertilizer and to a certain extent this will contribute to the reduction of domestic demand of chemical fertilizer. This potential amount of bio-fertilizer obtainable values 83.04USD $(2,220.40$ ETB $)$ per day and 29,951.66 USD (800,881.29 ETB) per annum (Table 6) and this will reduce the annual budget required for chemical fertilizer. As Amigun and von Blottnitz (2010) noted, bio-fertilizer as a co-product of biogas production can also lead into an increase in fertilizer availability. Banks, et.al. (2011) noted that if someone utilizes biofertilizer, the users would increase total crop yields by 6-30\% under ideal agronomic conditions. Chukwu et al. (2011) stated that essentially, bio-fertilizer reduces water and soil pollution, loss of micro-organisms and beneficial insects. So, this study gave a clue of biofertilizers significance importance which holds promising future in reducing soil quality problems with optimum crop yield for users and farmers as well.

Table 4. Equivalent of Biogas from Abattoir Waste to other Fuels

\begin{tabular}{|c|c|c|c|c|c|c|c|}
\hline \multirow{2}{*}{$\begin{array}{l}\text { Duration/ } \\
\text { period }\end{array}$} & \multirow{2}{*}{$\begin{array}{l}\operatorname{Biogas}\left(\mathrm{m}^{3}\right) \\
\text { generated }\end{array}$} & \multicolumn{6}{|c|}{ Equivalent of fuels (Kg) } \\
\hline & & $\begin{array}{l}\text { Firewood/ } \\
\text { Charcoal }\end{array}$ & Kerosene & Diesel & Petrol & LPG* & Furnace oil \\
\hline Day & 130.17 & 455.6 & 78.1 & 65.1 & 91.1 & 58.6 & 52.1 \\
\hline Week & 882.40 & $3,088.4$ & 529.4 & 441.2 & 617.7 & 397.1 & 353.0 \\
\hline Month & $3,823.67$ & $13,383.9$ & $2,294.2$ & $1,911.8$ & $2,677.6$ & $1,720.7$ & $1,529.5$ \\
\hline Year & $46,951.72$ & $164,331.0$ & $28,171.0$ & $23,475.7$ & $32,866.2$ & $21,128.3$ & $18,780.7$ \\
\hline
\end{tabular}

Table 5. Carbon dioxide emission reduction potential of using biogas in relation to other fuels

\begin{tabular}{|c|c|c|c|c|c|c|}
\hline \multirow[t]{2}{*}{ Fuels } & \multirow{2}{*}{$\begin{array}{l}\text { Power } \\
\text { generation } \\
\text { potential* }\end{array}$} & \multirow{2}{*}{$\begin{array}{l}\text { Standard } \\
\text { emission } \\
\text { potential* }\end{array}$} & \multicolumn{4}{|c|}{ Amount of $\mathrm{CO}_{2} \quad(\mathrm{~kg} / \mathrm{kWh}$ of fuel $)$} \\
\hline & & & Emission & Reduction** & Emission & Reduction** \\
\hline Biogas & $6 \mathrm{kWh} / \mathrm{m} 3$ & 0.09 & 220.90 & 0.00 & 79,729.49 & 0.00 \\
\hline Kerosene & $12 \mathrm{kWh} / \mathrm{kg}$ & 0.26 & 638.17 & 417.27 & $230,329.60$ & $150,600.10$ \\
\hline Petrol & $9.06 \mathrm{kWh} / \mathrm{L}$ & 0.26 & 638.17 & 417.27 & $230,329.60$ & $150,600.10$ \\
\hline Diesel & $9.8 \mathrm{kWh} / \mathrm{L}$ & 0.24 & 589.08 & 368.18 & $212,612.00$ & $132,882.50$ \\
\hline LPG & $12.2 \mathrm{kWh} / \mathrm{m} 3$ & 0.24 & 589.08 & 368.18 & $212,612.00$ & $132,882.50$ \\
\hline
\end{tabular}


Table 6. Bio-fertilizer potential of HMA waste and its cost benefits

\begin{tabular}{|c|c|c|c|c|c|}
\hline $\begin{array}{l}\text { Duration/ } \\
\text { Period }\end{array}$ & $\begin{array}{l}\text { Abattoir waste } \\
\text { generated }(\mathrm{Kg})\end{array}$ & $\mathrm{DM}^{*}(\mathrm{Kg})$ & $\mathrm{VS} * *(\mathrm{Kg})$ & $\begin{array}{l}\text { BFY potential } \\
(\mathrm{Kg})\end{array}$ & $\begin{array}{l}\text { BF Cost Estimation } \\
\text { USD(ETB) }\end{array}$ \\
\hline Daily & $2,456.04$ & 368.41 & 313.15 & 180.52 & $83.04(2,220.40)$ \\
\hline Weekly & $16,649.08$ & $2,497.36$ & $2,122.76$ & $1,223.70$ & $562.90(15,051.51)$ \\
\hline Monthly & $72,144.72$ & $10,821.71$ & $9,198.45$ & $5,302.64$ & $2,439.21(65,222.47)$ \\
\hline Annually & $885,881.60$ & $132,882.24$ & $112,949.9$ & $65,112.30$ & $29,951.66(800,881.29)$ \\
\hline
\end{tabular}

Conclusion: In general, the present study demonstrated that the HMA has a favorable potential for generating biogas and bio-fertilizer if biogas technology or anaerobic digestion plant is used. In addition, the technology is expected to reduce or solve the chronic SWM problem and will positively impact sectors such as energy, agriculture, economy, public health and the environment. Considering all these benefits, the Hawassa city municipality should think forward to install and use appropriate biogas technology as a sustainable waste management option. Furthermore, additional studies are required to see the biogas and bio-fertilizer potentials of liquid waste released from the abattoir and the huge amount of organic waste generate form Hawassa city.

\section{REFERENCES}

Adeyemi, IG; Adeyemo, OK. (2007). Waste management practices at the Bodija abattoir, Nigeria. International J. Environ. Stud. 64(1): 7182

Adeyemo, O; Adeyemi,I; Awosanya, E. (2009). Cattle Cruelty and Risks of Meat Contamination at Akinyele Cattle Market and Slaughter Slab in Oyo State, Nigeria. Trop. Anim. Health Prod.,41:1715-1721.

Adzabe, K; Asenso, BG; Bensah, EC; Dery, E; Hussein, AJ; Mensah, MY; Pinto, H; Sarpong, MD; Thompson, M; Quist-Therson, NNE.(2005). Development of a Biogas Plant for the Kumasi Abattoir Ghana. Vol.1 pp.972

Ahaneku, IE; Njemanze, CF. (2015). Flow Analysis of Abattoir Solid Waste Management System in Minna, Nigeria; Res. J. Dairy Sci., 41(2): 165172.

Amigun, B; Blottnitz, HV. (2010). Capacity-cost and location-cost analyses for biogas plants in Africa. Resources Conservation and Recycling, 55: 6373.

Aniebo, AO; Wekhe, SN; Okoli, IC. (2009). Abattoir Blood Waste Generation in River State and its Environmental Implications in the Niger Delta. Toxicol. Environ. Chem.; 91: 619-625.

Arthur, R; Baidoo, MF; Antwi, E. (2011) Biogas as a potential renewable energy source: a Ghanaian case study. Renew. Energy. 36: 1510-1516.

Banks, C. (2009).Optimization of anaerobic digestion to provide energy output via conversion_ retrieved from www.forestry.gov.uk/pdf/.../rrps_AD250309_opt imising anaerobic digestion.pdf (Accessed March 2016).

Banks, CJ; Chesshire, M; Heaven, S; Arnold, R. (2011). Anaerobic digestion of source segregated domestic food waste: performance assessment by mass and energy balance. Biores.. Technol. 102(2): 612-620.

B-sustain.(2013a). Environmental and Social Benefits of Biogas Technology. Retrieved from: http://www.bsustain.in/faqs.html (accessed in March 2015).

B-sustain.(2013b). Biogas equivalent to Fossil Fuels and its emission comparison. Retrieved from: http://www.bsustain.in/faqs.html (accessed in March 2015).

Chukwu, O. (2008). Analysis of Groundwater Pollution from Abattoir Waste in Minna, Nigeria. Res. J. Dairy Sci. 2(4): 74-77. 
Chukwu, O; Adeoye, PA; Chidiebere I. (2011).Abattoir wastes generation, management and the environment: Minna, Nigeria; Inter. J. Biosciences, 1(6):100-109.

CIA (Central Intelligence Agency). (2008). "Ethiopia" World Fact book. Retrieved from: https://www.cia.gov /et.html (Accessed in March 2016).

Cvetković, S; Radoičić, TK; Vukadinović, B; Kijevčanin, M. (2014).Potentials and status of biogas as energy source in the Republic of Serbia. Renewable and Sustainable Energy Reviews, 31:407-416.

CSA (Central Statistical Authority).(2015). Hawassa Branch. 2015. The 1999 Population projection of Hawassa city, 2013/14 Statistical Abstract, Hawassa, Ethiopia.

Dekelver, G., Ruzigana, S., and Lam, J. 2005. Report on the Feasibility Study for a Biogas Support Programme in the Republic of Rwanda. SNV, 2005.

Deublien, D; Steinhauser, A. (2008). Biogas from Waste and Renewable Resources, Wiley-VCH Verlag GmbH and Co; pp27-83.

EEPCO (Ethiopian Electric Power Corporation). (2015). Available on http//: www.ethio.energy conversion resource (Accessed Feb. 2015).

Electrigas. (2016). Biogas Frequently Asked Question (FAQ). Retrieved from: https://www.Electrigas.com/faq_en. $\quad \mathrm{htm}$. (Accessed Dec 2015).

FAO (Food and Agriculture Organization).(2010). Global Forest Resources Assessment, 9-44. Main Report 163
Frederick, A; Ayum, TG; Gifty, AA; Samuel, A. (2010). Microbial Quality of Chevon and Mutton Sold in Tamale Metropolis of Northern Ghana. $J$. Appl. Sci. Environ. Manage; 14 (4): 53-55.

Gautam, R; Bara, S; Herat, S. (2009). Biogas as a sustainable energy source in Nepal: present status and future challenges. Renew. Sustain. Energy Rev., 13 (1): 248-252.

Krubel, W. (2015). Investigation on storm drainage system problem of Hawassa city. MSC Thesis, Department of Civil Engineering, Institute of Technology, Hawassa University, Hawassa, Ethiopia.

Mummed, YY; Webb, EC. (2015). Operation Facilities and management practice.Afr. J. Agric. Res. 10(7): 623-630.

Ngumah, CC; Ogbulie, JN; Orji, JC; Amadi, ES. (2013). Biogas Potential of Organic Waste Nigeria, J. Urban Environ. Engineer. 7(1):110116

Oruonye, ED. (2015). Challenges of Abattoir Waste Management in Jalingo Metropolis, Nigeria; Inter. J. Res. Geog.1(2):22-31

Rabah, AB; Baki, AS; Hassan, LG; Musa, M; Ibrahim, AD.(2010). Production of Biogas using Abattoir waste at Different Retention Time. Sci. World J.5(4). 23-26.

Rohstoffe, FN. (2009). Biogas basisdaten Detschland - Comrehensive overview of the biogas station in Germany. Retrieved from: https://www,fnrserver.de/ftp/pdf/literatur/pdf_185basisdaten_biogas_2009. (Accessed Dec 2015).

White, AJ; Kirk, DW; Graydon, JW. (2011). Analysis of small scale biogas utilization systems on Ontario cattle farms. Renew. Energy, 36: 10191025. 